DE DE GRUYTER

OPEN

DOI: 10.1515/jolace-2016-0036

\title{
Teaching Jessica: race, religion, and gender in The Merchant of Venice
}

\author{
Efraim Sicher, Ben-Gurion University of the Negev, Israel \\ sicher@bgu.ac.il
}

\begin{abstract}
The Jew's "fair daughter" in Shakespeare's play The Merchant of Venice converts and marries a Christian, Lorenzo. Recent attention, however, to changing ideas of race and identity in the early modern period has brought into question the divisions of Christian/Jew/Moor. Can Jessica convert and no longer be considered the Jew's daughter? As "gentle" and "fair" is she to be considered gentile and in no way dark (spiritually or racially)? Jessica's conversion has apparently little religious meaning, but rather she is saved from the Jew her father by marriage to Lorenzo, who becomes Shylock's heir. Is Jessica's conversion to be considered a matter of convenience that might, as Launcelot quips, raise the price of hogs, or is it also to be counted as an ideological and racial conversion that reveals underlying anxieties about gender, sexuality, and religious identity? This essay attempts to argue against the grain of the performance history of The Merchant History, which often downplays the role of Jessica or revises the text of the play, and returns to the text in order to contextualize the conversion of Jessica in contemporary discourses of gender, race, and religion in England's expansionist colonialism and proto-capitalist commerce. The conversion of Jessica can be seen in that context as an exchange of monetary and ethical value, in which women's sexuality also had a price-tag. These questions have implications for the teaching of the play and for the understanding of its concerns with unstable sexual, religious, and national identities.
\end{abstract}

Key words: Shakespeare; The Merchant of Venice; gender; religion; sexuality

\section{Introduction}

Much has been written about the figure of Shylock in Shakespeare's play The Merchant of Venice (Gross, 1994; Sinsheimer, 1947). Indeed, the prolific criticism, not to mention the plays and novels written to counter the image of Shylock (Nachshon \& Shapiro, Eds., at press), seems excessive for this character's limited role in the play--Shylock is already defeated and exits at the end of Act IV, and while the pound of flesh motivates Antonio's readiness for martyrdom in the trial scene, it does not outweigh the casket test with its attendant and overriding theme of love and harmony, played out in Act V. While attention has been paid to Jessica (Delgado, 1994; Kaplan, 2007; Slights, 1980), her conversion has not been 
sufficiently considered (Berley, 1999), though critics have strained to find theological grounds in order to exonerate her (Dobbins \& Battenhouse, 1976), or exerted themselves to rehabilitate her reputation as a literary character on textual grounds (Slights, 1980). M. Lindsay Kaplan, however, relates Jessica's conversion to medieval theories of reproduction, as well as ideas about the immutable nature of the Jew that was represented by inherited somatic or biological characteristics (Kaplan, 2007; Metzger, 1998). The Dutch scholar Lieke Stelling (2007) has claimed Jessica as a renegade whose voluntary conversion opens up new possibilities of early modern identities, and Michelle Ephraim (2008) reads Jessica in the archetype of Jephtah's daughter in the Bible, a sacrificial figure who becomes a victim of patriarchy and power relations. Jessica's challenge to gender hierarchy has become a byword of contemporary scholarship, in particular as an example of the contingency of gender boundaries which, like other personal and collective identities, are based on social and cultural constructs that were being undermined in the early modern period by changing attitudes towards individuality and subjectivity, as well as religion, and sexuality, and were subversively performed through corporealized signs and discursive strategies that spell what Judith Butler would call "gender trouble" (Cox, 2000). Nevertheless, all too often critics ignore the ambiguities built into the text and continue to juxtapose essentialized concepts of "Christian/Jew" in a test of whether the play is "anti-Semitic," or reread the play from the vantage point of modern Jewish identities, looking for evidence before or after Shakespeare's time for the real presence of Jewishness in the play (Adelman, 2008; Levin \& Watkins, 2009, pp. 85-110).There have also been attempts by directors and actors to wrench the play from Shakespeare and interpret it as a contemporary sermon on racism and anti-Semitism.

Every production is, in a sense, a new play, but reinterpretation of the play from a post-Holocaust standpoint in scholarship and in performance history has tended to focus on Shylock as the crux of the problem of anti-Semitism (though that term would have been an anachronism in Shakespeare's day), which is nowhere more painful and inextricable than in Germany (Ackermann and Schülting, 2011). Middleton (2015) has given us a useful performance history of Jessica on the postHolocaust stage that shows the multiplicity of identities in the staging of Jessica which often reduces her to a counterpart for a sympathetic Shylock or typifies her as a rebellious teenage daughter running away form a hard-hearted father, bypassing the issue of religious conversion or stressing the need for respect of difference. Trevor Nunn's 1999 production at the National Theatre (made into a movie in 2001) follows a trend to interpret Shylock in the wake of the Holocaust as the victim of cruel persecution and an intolerant society. He is played by Henry Goodman as a modern Orthodox Jew who speaks Yiddish to his daughter; in Nunn's film version he sings the Hebrew Sabbath melody Eshet khayil ("Woman of Valor") together with Jessica (played by Gabrielle Jourdain), as Shylock recalls his 
deceased wife Leah, whose portrait he peruses while considering whether or not to answer Bassanio's invitation to dinner. This episode is inserted just at the point (II, v) when Launcelot (played by a Black) gives Jessica Lorenzo's message with instructions about their elopement. In this interpretation, Jessica is running away not because she wants to convert, but because she wants to escape her father's oppressive house and his domineering character. She discovers too late her mistake and the price she must pay to be accepted as a Christian, a clear parable of the lesson learned by assimilated Jews in the twentieth century. In Act V, scene I Jessica breaks down at the moment of Portia's return to Belmont when the couples are to be reunited and fidelities renegotiated. While Lorenzo is jubilant over the gift of the Jew's wealth, Jessica wails the lines of Eshet khayil (the verses from Proverbs usually sung at the Sabbath eve dinner table), falling to her knees as she understands her loss of family and home. The intrusion of Hebrew emphasizes a moment of Jewish identification that undoes Shakespeare's troubled tranquility and the restitution of stability in Portia's homecoming, but it also rewrites the Jewish alien as a legitimate cultural voice.

Besides the stereotypical Jewish daughter opposite Al Pacino's Shylock on Broadway in 2010 (directed by Daniel Sullivan), Jessica has been coopted as a rebellious Jewish daughter on the New York stage played by Dara Seitzman (Revolving Shakespeare Company, 2002), as well as being conscripted by postmodern Jewish novelists, as in Erica Jong's bawdy novel, Serenissima (1987, later retitled Shylock's Daughter: A Novel of Love in Venice), a fantasy about an erotic relationship between a Jewess and the Bard. A children's novel by Mirjam Pressler, Tochter (1999), translated as Shylock's Daughter (2000), retells Jessica's story from a post-Holocaust perspective of anti-Semitism and assimilation. Michael Scrivener, in his book on the figure of the "Jew" in nineteenth-century British culture, follows Janet Adelman in a revisionist reading of Jessica as a tragic figure in the spirit of Romantic performance of Shylock from Edmund Kean on, immortalized in Maurice Gottlieb's 1876 painting Shylock and Jessica (Scrivener, 2011). This has become an icon for modern representation and promotion of the play (for example, in the National Theatre poster for Nunn's production). Few contemporary critics take Jessica seriously as a Shakespearean (rather than Jewish) type, and few ponder the significance of Jessica's (rather than Shylock's) conversion. ${ }^{1}$

I would take issue with attempts to introduce Jessica into a debate between Judaism and Christianity or to read Shakespeare's play from the standpoint of postmodern identity politics or American Jewish communal concerns about

1 Exceptionally, Aaron Landau (2006) has compared Jessica's conversion with Zoraida's conversion from Islam in "The Captive's Tale" in Cervantes' Don Quixote as an example of a gendered cross-cultural paradigm. 
assimilation. Instead, I would like to come back to Shakespeare's text, and turn to the question of why Jessica converts, a conversion that is not staged and often puzzles modern audiences (though it would surely not have troubled Shakespeare's contemporaries). I believe Jessica's conversion may hold the key to central ideas in the play that are connected with equally compelling and no less topical concerns such as colonialism, hybridity, "Englishness," race, and sexuality, which scholars of early modern England have pinpointed as key issues in Elizabethan society and culture (Loomba, 2002; Shapiro, 1996). Why indeed does Jessica have to convert? Many students ask this question. I want to suggest that Jessica's conversion is a key to a preoccupation with gender, race, and color in Shakespeare's The Merchant of Venice, in fact with anxieties about boundaries in these categories that were shifting in the early modern period. I would go as far as to say that Jessica's conversion carries a far greater weight in the meaning of the play than Shylock and the bond, which in fact is part of a larger plot (the love story and Portia's bonding to her father's will in the casket contest of marriage suitors).

\section{Early modern conversions: Fidelity and Inconstancy}

Firstly, let us briefly consider the early modern view of whether the Jew's body was convertible. Several English theologians debated whether Jewish biological identity -including the Jewish smell, or foetor judaicus, - could be washed away by baptism, and asked what happened to the Jewish body when it entered the communion of the Christian commonwealth, or wondered how it would be affected by a relapse (Shapiro, 1996, pp. 170-71). These anxieties are not unconnected with the question of sincerity in conversion in a country torn apart by Protestant and Roman Catholic claims and counter-claims. In his enormously popular Acts and Monuments (1570), John Foxe questioned the efficacy of forced conversion, attacked its abuse, and critiqued the persecution of heretics by the Spanish Inquisition, which turned against anyone who was deemed theologically wayward or who fell victim to political intrigue and envy. The secret ways of the Inquisition, Foxe averred, trapped and condemned many a true believer (Cattley, Ed. 1837. Vol. 4, pp. 451-2). If such barbarous practices were to send shivers down Elizabethan spines, how much more horrible was the fate of Archbishop Thomas Cranmer, who had been forced to convert to Catholicism under Mary Tudor but recanted shortly before his execution in 1556 . Foxe, who paints a graphic picture of Cranmer's martyrdom and praises the Archbishop's steadfast faith to the last, apparently speaks for religious tolerance and against forced conversion (Cattley, Ed. Vol. 8, pp. 3-19). In his account of the pogrom of London Jews at the time of the coronation of Richard I in 1189, he described the forced conversion of one Jew who thereby sought to save his life and who was subsequently allowed to revert to Judaism after the King's inquiry into his forced conversion, but this is reported negatively, as reversion to worship of the devil (Cattley, Ed. Vol. 2, pp. 276-77). 
However, Foxe's attitude toward Jews was increasingly hard and implacable (Achinstein, 2001, 109-11). In the following description of the 1190 York massacre, when Jews killed themselves rather than convert, Foxe repeated the widely believed blood libel when he declared that the victims deserved what befell them on account of their annual crucifixion of a Christian child on Good Friday (Cattley, Ed. Vol. 2, p. 277).

Contact with Jews in the strategic eastern Mediterranean gave opportunities of their candidacy for conversion. Foxe relates an apocryphal tale of a converted Jew in Constantinople, who was martyred by the Turks and whose body miraculously did not putrefy, demonstrating the redemptive efficacy of baptism, which presumably washed away his "Jewishness" (Cattley, Ed. Vol. 4, p. 555). In his Sermon Preached at the Christening of a Certaine Jew, at London (trans. James Bell, 1578) Foxe voiced his hope that the example of conversion of a Jew transported out of Barbary, who renounced "at the last the natural contumacy of his native country," would lead to the remnant of the "circumcised race" joining the nations of the world embracing faith in Jesus, a supranational faith in the spirit of Paul's notion of a Christian nation. Yet as an example of infidelity he gives the Jews' "unbelief, which being more noisome than any pestilent botch, may rightly and properly be called the Jewish infidelity, and it seemeth after a certain manner their inheritable disease, who are after a certain sort, from their birth, naturally carried through perverse frowardness, into all malicious hatred, and contempt of Christ, and his Christians" (Foxe, p. 303). These examples of conversion of male Jews uncover the ambiguities and unease about the Jewish body: is "Jewish" infidelity inherent and passed on together with the curse that was believed to afflict Jews from one generation to the next, or could conversion put an end to the Jews' stubborn misbelief without fear of relapse and treachery? The usual story in the conversion narrative is that the wicked Jews are given a chance to recognize Christianity as the true religion through the working of a miracle, as a result of which they convert, thus saving their souls if not their bodies. If there is a "miracle" in The Merchant of Venice, it is Portia's intervention in the trial, not the Virgin Mary's, and the only voluntary conversion is Jessica's.

In any case, there seem to be few theological qualms in either The Jew of Malta or The Merchant of Venice. The paradigm of wicked Jew-father and desirable fair daughter is exemplified by the wicked Barabas and the beautiful Abigail, as well as Shylock and Jessica-Berenice in Maria Edgeworth's Harrington (1817) and Rebecca in Sir Walter Scott's Ivanhoe (1819) are anti-Jessicas who confirm the stereotype but subvert the requirement of conversion by insisting on endogamy in the resolution of the plot. Michael Ragussis sees an intimate link in Shakespeare's play between religious conversion and the trope of conversion in comedy, a transformation of identity which tests other forms of "conversion" in the play (Ragussis, 1995). Indeed, Jessica has some affinity with the father-daughter pair of 
the commediadell'arte and joins Portia and other daughters in conflict with their father's will in the choice of marriage partner in Shakespeare's plays, sometimes with comic resolution, for example, in Midsummer's Night Dream; Olivia Delgado de Torres casts Jessica in a comparative "daughterology" of Shakespeare's plays (Delgado, 1994). The Shylock-Jessica pair cannot apparently be separated, since Jessica's rebellion makes no sense without Shylock's story, yet, unlike Abigail in The Jew of Malta, Jessica does marry a Christian and has a life on the stage independent of her father.

At first glance, there seems little serious concern with miscegenation (itself an anachronistic term), notwithstanding Portia's prejudice against Morocco, who recommends his racial profile as a mark of sexual prowess (2.1.1-12). Abigail in The Jew of Malta is considered a suitable partner for a Christian noble. Don Mathias regrets that Abigail landed up in a nunnery rather than a bed and Friar Barnardine (one of two "religious caterpillars" who compete for the soul of the Jew) is grieved by her death because she died a virgin! Barabas rails against his daughter's disloyalty to his faith and tribe, yet Abigail eventually converts for real as a result of her father's Machiavellian strategies in which she too (like Iphigenia) has been sacrificed; however, she does not set out to betray him (Charney, 1979). By contrast, Jessica intends from the beginning to disown her Jew-father, who would rather she marry someone from the stock of "Barabbas" (4.1.190-92), the thief released instead of Jesus (Mark 15:6-15); she wishes to marry Lorenzo, who steals the Jew's daughter and with her his gold. Unlike Abigail, Jessica has no part in her father's evil doing and has no part in the blood vengeance against the Christian. Yet her desertion motivates Shylock's determination to demand his bond: Solanio and Salario warn that Shylock will make Antonio pay for both the loss of his daughter and his gold (2.8.25) and taunt Shylock with his double loss in act 3 scene 1 , provoking him to revenge, "Let him look to his bond."

I argue that the issue of convertibility is not restricted to conversion of the Jews, but serves as a malleable trope for inconstancy at several levels. In order to understand the conversion of Jessica in the perspective of the play as a whole, it is important to bear in mind the unstable complexity of ideas in The Merchant of Venice, in which Jessica, not Shylock, stands at the center of the notion of conversion. Conversion here is not so much an act of faith, but a conversion of value that is pragmatically convenient and reflects unstable, often fuzzy, boundaries of ethnic, racial, and sexual identities. There is no doubt that early modern England was witness to much anxiety about conversion, as the nation switched between Protestant and Catholic churches, and suspicion was cast on recusants, closet Papists, and "Judaizers" (Questier, 1996); to say someone "turned Turk" was to suspect them of betrayal (see the study of the renegade of the English stage in Vitkus, 2008). To take Jessica's conversion seriously as a typical search for spiritual salvation or (anachronistically) for civic emancipation (Lupton, 2005) 
misses the point that it is anxiety about changing and unstable identities which comes subversively to the fore in The Merchant of Venice.

One way of defining Englishness at a critical moment of formation of the nation was to delineate the Other, so that the construction of the figure of the "Jew" projects shifting boundaries of racial, religious, or gender difference in a changing economic climate and global mercantile and strategic environment (see Shapiro, 1996). What with the incessant flow of foreigners in English ports and the frequent encounters with unfamiliar peoples in the new worlds whose religions and cultures did not fit European paradigms of White Christian "civilization," the Englishman would be hard put to name a precise and consistent classification of nationhood (see Shapiro, 1996). In fact, the terms nation, religion, color, and race were in flux at the time as England adjusted its self-identity vis-à-vis its emerging role as a major colonial power and trading empire. In particular, commercial contact brought home the threat of miscegenation and infiltration which would harm English economic interests at home (Hall, 2006; see Bovilsky, 2008). Religious, racial, and national difference was becoming further destabilized by Moors, Negroes, Romany, and others who were claiming charity on England's shores, not to mention the tensions in gender and class roles shown by crossdressing (Howard, 1988; Bullough \& Bullough, 1993; Cressy, 1996) and passing (Mounsey, 2001), fake or disguised identities (a deception reflected in the wording of the 1597-98 vagrant laws) (Eliav-Feldon, 2012). The clandestine presence in England of Spanish and Portuguese converses is only one example of false identities and "counterfeit professions" in an atmosphere of intrigue, espionage, and suspicion. Marranos, a pejorative term in current usage for a renegade and rogue, professing Christianity but secretly practicing some form of crypto-Judaism, could be considered the archetypal Renaissance man, disguised and secretive (Berek, 1998; Campos, 2002; Shoulson, 2013, pp. 33-34).

Jews were aliens everywhere, not confined to one country (though Jessica refers to her father's "countrymen"), and so were to be considered a danger within the nation because they embodied a cultural and racial difference that was impermeable to conversion (Loomba, 2002). There had been, officially, no Jews in England since the expulsion of 1290, but there was a number of merchants or musicians and other persons attached to the court, who may have been of New Christian descent, though the legend of the Beautiful Jewess, Maria Nuňes, captured by English pirates while en route to refuge and safety in Holland, who rode with the queen in her carriage, is historically inaccurate (Bodian, 1999, pp. 23-24). Gratiano's reference to the hanged wolf in his speech in the trial scene (4.1.133-135) might allude to the infamous Dr. Roderigo Lopez, physician to Queen Elizabeth, who was executed for allegedly plotting to poison the English monarch in June 1594 (two years before the possible date for the first staging of The Merchant of Venice) (Modder, 1939/1960). In a popular engraving, "Lopez 
compounding to poison the Queen" (first published in Popish Plots and Treasons, 1606), Lopez is depicted as Judas, for whom the question is "how much will you give?," a clear reference to the secret identity of the "Jewish doctor," as he was called in his indictment (Green, p. 305). Marlowe's play about another conspirator, double-agent, and poisoner, The Jew of Malta was staged at the Rose just three days after Lopez was taken to the Tower, and Lopez's gruesome execution would have been in the public mind when The Merchant of Venice was first performed (Green, pp. 244-45, 307-311). The figure of Lopez, who was associated as a Jewish physician with Machiavelli and poisoning even before his trial and execution (Harris, 1998, pp. 79-87), fitted the image of the deceptive Maranno perfectly.

I would argue that the problematic relation of outer appearance and inner self (a juxtaposition that goes back to Matthew in the Christian scriptures) indicates an embodiment of the deceit in the religious and moral identity of the Jew to which Antonio draws attention in The Merchant of Venice when he refers to Shylock as falsely appearing to be a good apple that is rotten inside (1.3.93-94). Bassanio also draws on this opposition between material outside and spiritual inside when choosing the lead casket (3.2.73-80), an argument that he applies to both religion and law and that is not irrelevant to the trial scene. However much the Jew may satanically disguise himself, he remains internally unchangeable, and thus would be unconvertable.

The perfidious heresy of the Jews, who were classified as black (from contact with the devil, as well as from inherent filth), could not be changed any more than the "black Moor" could change his skin or the leopard could change its spots, in the Geneva Bible rendering of the well-known passage in Jeremiah 13: 23 (Loomba, 2002), a verse that can be related to the racial discourse in Othello. The Venerable Bede expounded the verse to mean that by casting off sin the "Ethiopian" can be "whitened" through baptism. However, other Christian commentators used the verse to show that, to the contrary, the Jews were, like the Ethiopian, unredeemable. Such allegorical readings did not remain in the realm of the metaphorical but related also to the somatic difference of the Jewish body. Medieval medicine and natural science took this spiritual analogy to be empirical fact, adducing the Jew's blackness to divine punishment and irredeemable sinfulness, yet blackness could also be attributed to external factors, such as climate and geographical location, that could change over time. Blackness was also associated with melancholy and inclinations (see Resnick, 2012). In late medieval romance there are many examples of representations of embodied Jewish or Muslim otherness which are immutable despite baptism, suggesting a biological essence inseparable from religious difference (Resnick, 2012,pp. 294-299; Ziegler, 2009, pp. 198-199).

While it was the male who was thought to determine lineage, that is, "race" and "class" (Loomba, 2002), it was widely believed that the woman's thoughts at the 
time of coitus or during pregnancy could affect the color and appearance of the embryo (an oft-cited example was Jacob's genetic experiment with Laban's sheep in the Bible, to which Shylock refers in his defense of usury). This would give Jessica a significant role in marriage with a Christian, in which color and physiology were significant. Jew and Moor were, in the thinking of Shakespeare's day, each an alien Other, and this is reflected in the construction in medical knowledge of an inherent physiological difference, with all that this implies for breeding and miscegenation (Japtok \& Schleiner, 1999). ${ }^{2}$

\section{The conversion of Body and Spirit}

Sexual fantasy clearly played a part in the drive to convert Jewish women who were perceived as both beautiful and eligible for conversion because, unlike wicked, ugly Jewish men, they were not cursed for abusing Jesus on the way to crucifixion but had tended the Christians' savior compassionately, like Mary Magdalene. Inter-racial sexual relations were regarded with a mixture of aversion and derision, yet it was invariably the Jew's daughter, not any male offspring, who was the desirable partner and ripe for conversion. It was widely believed that Jewish women preferred intercourse with uncircumcised men (Sir Thomas Brown, 1646, cited in Bulwer, 1654, p. 378). From a Freudian standpoint, desire doubles with fear of the Other in fantasies of miscegenation, and in early modern Europe tales abounded of sex with Black or Asiatic slaves, titillating readers but warning them of the boundaries of religious and power hierarchies (Young, 1995; Groebner, 2009). Whiteness was a measure of beauty, as distinct from the blackness of the Moor (a confused classification of blacks in northern parts of Africa at the time), which was a sign of dirt and evil, danger and repulsion (Winthrop, 2000). Besides the repeated pun in the play on gentle/Gentile, the association of "fair" with color and beauty emphasizes Jessica's whiteness (Lorenzo praises the fair hand that wrote him a letter [2.4.12]), as well as virtue and justice (Antonio's "fair flesh" signifies more than just weight and value).

A theological argument would say the sins of the father are laid upon the children and no baptism can wash away the inherited guilt and blackness of the Jews. Launcelot jokes in Act 3, Scene 5,

2 Emily Bartels, however, insists on the distinction between the Jew, who is allowed sufficient humanity to demonstrate the monstrosity of his behavior, and the Moor, who, on the early modern stage, "is uniquely poised to negotiate, mediate, even transform the terms of European culture" (2008, p. 15). 


\begin{tabular}{|c|c|}
\hline JoLaCE & $\begin{array}{r}\text { Journal of Language and Cultural Education, } 201 \\
\qquad 1 S S N 1339-4045 \text { (print), 1SSN 1339-4584 }\end{array}$ \\
\hline LAUNCELOT & $\begin{array}{l}\text { Yes truly, for look you, the sins of the father } \\
\text { are to be laid upon the children: therefore I } \\
\text { promise you, I fear you. I was always plain with } \\
\text { you and so now I speak my agitation of the matter. } \\
\text { Therefore be a'good cheer for truly I think you } \\
\text { are damned. There is but one hope in it that can do } \\
\text { you any good, and that is but a kind of bastard } \\
\text { hope neither. }\end{array}$ \\
\hline JESSICA & And what hope is that, I pray thee? \\
\hline LAUNCELOT & $\begin{array}{l}\text { Marry, you may partly hope that your father got you } \\
\text { not, that you are not the Jew's daughter. }\end{array}$ \\
\hline JESSICA & $\begin{array}{l}\text { That were a kind of bastard hope, indeed- so the } \\
\text { sins of my mother should be visited upon me! }\end{array}$ \\
\hline LAUNCELOT & $\begin{array}{l}\text { Truly then, I fear you are damned both by father and } \\
\text { mother: thus when I shun Scylla, your father, I } \\
\text { fall into Charybdis, your mother. Well, you are } \\
\text { gone both ways. }\end{array}$ \\
\hline JESSICA & $\begin{array}{l}\text { I shall be saved by my husband. He hath made me a } \\
\text { Christian. }(3.5 .1-20)\end{array}$ \\
\hline
\end{tabular}

Launcelot's teasing insinuates that Jessica cannot throw off her father's religion without also cutting herself off from his circumcised body by having a Christian "get" her. The Second Folio reading ("beget") suggests the possibility that Jessica is not her father's child (Adelman, 2008, pp. 71-72). ${ }^{3}$ Marriage to Lorenzo is an act of conversion (a reference to I Corinthians 7-14) that frees Jessica from being the Jew's daughter, but this raises socioeconomic anxieties about the influx of converted strangers. Launcelot quips,

This making Christians will raise the

price of hogs; if we grow all to be pork eaters, we shall not shortly have a rasher on the coals for money.

$(3.5 .23-5 ; 52)$

Joking aside, Jessica is to be "saved" by her husband and will no longer be her father's daughter, so that birth would not override an incontrovertible difference of nation, color, race, and religion.

3 Adelman infers that an Elizabethan audience would have heard "begets" rather than "gets" with its association of possession (2008, pp. 71-72). Harris and Rubinstein, however, read "get" as consistent with Launcelot's sexual innuendoes throughout this scene that make light of Jessica's virtue (2004, pp. 14-15). 
Jessica becomes a Christian's wife through a sexual and gender transformation (Metzger, 1998). When Jessica is cross-dressed as a boy page, the covering of her sex that "garnishes" Lorenzo's appetite for her body, both masks her alien status and suggests a switching of gender identities, alluded to in the bawdy pun of Jessica (played by a Christian male actor) holding a "candle" (penis) to her "shames" (genitals) (Harris \& Rubinstein, 2004, p. 14; Jardine, 1983, pp. 29-30). Cross-dressing is appropriate for the Venetian carnival setting, but whatever Freudian significance it may have (Berley, 1999), this common early modern stage device draws attention to an inversion of social and sexual identities, which Shakespeare uses in his plays to deflect the threat of male submission and to playfully insinuate homoeroticism (Bromley, 2012, pp. 73-75). Like the switch of religion, cross-dressing offers yet another exchange in the commodity-value of bodies (see Mentz, 2003; Shell, 1982). Inversion of social and sexual identities, moreover, enables conversion of the feminized "Jewish" body into a Christian body (see Kruger, 2006, pp. 96-109). While men could be saved through the grace of Jesus, women were the gendered Other, who (at least in medieval Christian hermeneutics) had to transcend their sex to reach salvation. The circumcised Jew, however, who lacked a full phallus and was thus gendered as Other, had first to convert (Lampert, 2004, pp. 29-35). Jessica's conversion is thus an exchange of both sexual and monetary value, as she converts the Jew's money and her body to Christian use, a natural joining, in Reformation discourse, to the spirit of the Christian nation, in contrast to the unnatural Jewish body (Blank, 2003, pp. 94-96).

Yet this act of conversion must still overcome the difference of blood. Whatever the fantasies of castration and emasculation pertaining to circumcision (Katz, 1999) in Solanio's obscene jesting about Shylock's manhood in Act 3, scene 2 (after Jessica has fled with Lorenzo and the gold), Salerio makes a significant point: "There is more difference between thy flesh and hers / than between jet and ivory; more between your bloods / than there is between red wine and Rhenish" (3.1.3538). Is it possible to reverse the Jewish difference of blood, a difference that Christian theologians believed derived from the Jews' primal sin in calling the blood of Jesus on their heads (Matthew 27.25), as Shylock calls his deeds on his head in the trial scene? Jessica has herself testified in 2.3:

Alack, what heinous sin is it in me

To be ashamed to be my father's child!

But though I am a daughter to his blood

I am not to his manners. O Lorenzo,

If thou keep promise, I shall end this strife-

Become a Christian and thy loving wife. (2.3.17-22)

This would distinguish the inheritance of blood from the inheritance of morals and suggests an argument for the possibility of a moral or spiritual conversion that 
can override, or at least excuse, unredeemable tainted Jewish blood without need of a transfusion. This possibility indicates a shift from a biological determinism to moral choice, and it sets the stage for a move in the last act, which comes after Shylock's forced conversion and his humiliating exit from the play, to a more metaphysical resolution of the inconstancy of conversion and the vagaries of religious and racial boundaries.

\section{Harmony and its Discontents}

The final act transports us to Belmont, in some ways an alternate space to Venice and in some ways an extension of it. Here money is converted to love, but conversion can itself call into question the constancy of love and the value of exchange. The Renaissance stamp of humanism is evident in the typical romantic ending, the coupling of the lovers:
LORENZO
In such a night
Did Jessica steal from the wealthy Jew,
And with an unthrift love did run from Venice
As far as Belmont.
JESSICA
In such a night
Did young Lorenzo swear he loved her well,
Stealing her soul with many vows of faith,
And ne'er a true one.
LORENZO
In such a night
Did pretty Jessica, like a little shrew,
Slander her love; and he forgave it her.
JESSICA I would out-night you, did nobody come, But hark- I hear the footing of a man.

(5.1.19-31)

How can we understand this competition between the lovers over fidelity, cut short by (of all gendered choices) a man's footing? In fact, the series of mythic couples summoned by Lorenzo and Jessica suffer tragedy and (with the exception of Thisbe) betrayal, casting further doubts on the seriousness of a marital bond that depends on conversion ${ }^{4}$ and evoking a sense of inauspicious doom for the eloping lovers. Significantly, Jessica's example that trumps Lorenzo's Dido in their contest of classical myths is Ovid's Medea who triumphs through revenge, but who is also the giver of a magical gift to Jason in his quest to win the golden fleece, as

4 See Kaplan's extrapolation of these couples and its possible significance for Jessica's conversion (2007, pp. 27-29). Lampert (2004, p. 165) sees the allusion as further evidence of Jessica's incomplete conversion and aberrant sexuality; Berger explains the anomaly of Thisbe as bringing us back to Jessica's abandonment of her father (2010, p. 21). 
well as poisoning Jason's new wife and committing infanticide to avenge faithlessness (Tassi, 2011, p. 254). These insights into sexual relationships introduce irony into Gratiano's boast that they are the Jasons who have "won the golden fleece" (3.2.329). Not only is their fidelity tested and found wanting, but the moon-like inconstancy of human hearts reflects an anxiety about convertibility.

The play ends, not with revenge on the avenger, as in The Jew of Malta, but with conversion aided by Diana, rather than Mary, to the hedonistic lighthearted ways of Belmont. Diana is an agent of conversion who transformed Actaeon into a stag after he stumbled upon her bathing in her birthday suit (as portrayed in Titian's Diana and Actaeon, 1556-1559). Lorenzo's and Jessica's musings prepare for the homecoming of the metamorphosed Portia, hunter and (as the golden fleece) hunted object of desire; Portia and Nerissa have virtually converted their husbands into both stags and cuckolds (who were traditionally horned). Now the converted Jessica must learn to overcome the aversion in her father's house to sweet music, though the reason for her sadness, Lorenzo explains, is that her "spirits are attentive" (5.1.68); only music, he says, has Orpheus's power to transform (Oz, 1995).

A man without music is fit for "treasons, stratagems and spoils" (5.1.83) and is not to be trusted- one cannot but think of the treacherous Jew who shuts out of his house the harmony of music. In the harmonic music of the spheres, there is no place for the exacting retribution and mathematical law of the Jew in a Belmont of lightness and joy, merriment and love, even if harmony can only be dimly seen by mortal eyes and its cherubic music is inaudible (5.1.61-63) (Oz, pp. 188-91). The Jew's revenge has failed, and Antonio's readiness to martyr himself to the Christkiller has paid off the debt for the loan of his body for the advancement of his friend's wealth and sexual pleasure.

Commentators have ascribed Jessica's initial unease in Belmont to her status as a social outcast, not completely washed clean of her father's blood by baptism (Adelman, pp. 73-74); Graziano refers to her as an "infidel" (3.2.216) and a "stranger" (3.2.235).Yet there is scant evidence in the text to support any regret for her apostasy. Hamilton conjectures that Jessica's silence on her father's fate implies her feelings of guilt; in the 1987 Royal Shakespeare production, an explanation for her sad mood in Act 5 is given in having Jessica dressed differently from the rest of the Belmont crowd and in the final scene Antonio dangles a cross over her head as she falls down, stricken with grief (Hamilton, 2003, 51-52). Yet her story does not end, as one would expect in conventional conversion narratives, with transformation by a new faith or (as in Shylock's case) by humiliating defeat and submission. Indeed, the efficacy of conversion becomes as much a matter of teasing between Lorenzo and Jessica in the last act as do his vows of faithfulness, suggesting that both marital and religious fidelity are not constant, that hearts may be stolen as much as the Jew's money. 
Belmont's idyllic harmony seems a world apart from the rapacious moneygetting of Venice and Shylock's murderous menace, yet it offers a pertinent message about the anxieties of early modern capitalism and colonialism. Not for nothing does Portia compare the candle burning in her hall to "a good deed in a naughty world" (5.1.89). It is a moment that has its comic relief, which nevertheless does not detract from the ideal humility of the Christian Merchant who offers a moral substitution for the Jew-usurer's unyielding insistence on the merciless letter of the law, as well as a business ethics that responds to the current debate over usury and the risks of finance in the early modern economy (Cohen, 1985; Hinley, 1980; Nirenberg, 2013; Rosenshield, 2002). Antonio converts materialistic gain to the good, and his self-sacrifice closes the circle that opened the play with his sobriety and melancholy. Echoing Jessica's own cross-dressing that freed her from her father, Portia's and Nerissa's cross-dressing has unbound Antonio from Shylock and bound Bassanio in debt to Antonio. Antonio, who had bound himself for Bassanio by selling his body to the devil, is prepared to bind his soul for his friend's renewed fidelity (5.1.47-251). Antonio is rewarded with the return of part of his argosies, Lorenzo and Jessica with the gift after Shylock's death of half the Jew's estate. This gift symbolically confirms salvation through the "manna" (5.1.292) of material, not spiritual, abundance. Harmony has been restored, yet the conversions which have made this possible have raised questions about its durability and stability, reflecting concerns in early modern England about infidelity in conversion from Catholicism or Protestantism, as well as in credit and trust in commerce as England's mercantile fleet gained ground in global trade in competition with Venice.

All's well that ends well, yet the danger in which Antonio had placed himself must be understood as a serious one from which he is saved by a woman, Portia, who converted her gender identity in a transgressive act of cross-dressing and who nonetheless managed to get her will without breaking her father's. The laws of patrimony are broken only by Jessica, the Jew's prodigal daughter, who has symbolically emasculated the Jew by stealing his euphemistic "stones" (2.8.20-21; 2.9.22) (Lampert, 2004). Jessica has become one flesh with the Christian in a supersession of the Christian body over the Jewish threat to it, of grace over law, of music over usury, of luxurious contentment over barren breeding.

Shylock's conversion is a condition of Antonio's mercy, one clause in Christian clemency, not a punishment (as in Al Pacino's movie), but Jessica's conversion, inasmuch as the representational world of the play operates within English common law, ensures that she loses her female subjectivity when her property goes to the male heir (Lorenzo), who inherits Shylock's property as his "son." Similarly, Portia tells Bassanio that "Myself and what is mine to you and yours / is now converted" (3.2.171-2; 22) (Shoulson, 2013). In "converting" her wealth to Bassanio (3.2.166-67), Portia is a convertible coin (an "angel" in Morocco's pun 
[2.7.56]), which makes marriage a profitable transaction of trade and desire (Loomba, 2002), though Newman reads this exchange as a sign of a conservative society trading in women as objects, not partners, of marriage $(2009,59-76)$. However, when Portia calls on Bassanio to take into "account" her virtues (3.2.155158), the tension is evident between the spiritual and the material, between fair trade and excess, between purchase of goods and of human flesh. It is Portia who, in the trial scene, safeguards the commodity relations which, in Antonio's warning (3.3.31-32), the Venetians-and by extension the Elizabethans-have with strangers, who are perceived as an economic, cultural, and sexual danger that must be controlled. In the new conditions of intense and unregulated mercantile activity, legal and ethnic difference had to be redefined for the protection of the local and national economy from competition and piracy. In the Machiavellian marketplace that was the early modern Mediterranean, both the Jew's ducats and his daughter were equally profitable (Vitkus, 2008). As Jonathan Gil Harris has argued, the figure of the Jew in The Merchant of Venice, when compared with other contemporary figures of usurers, presents less the condemnation of unnatural breeding of money as a Jewish vice than an Elizabethan concern with transnational mercantilism (Harris, 2004, p. 53). ${ }^{5}$ On the face of it, the mythical narrative and theological archetype of the Jew's daughter have been transformed into a successful romance that fends off the racial, gender, and sexual risks of early modern commodity exchange, in which love, too, has a price and an exchange rate. If we can put aside the debate over the loaded question of anti-Semitism in the performance history of the play, we can see that Jessica's conversion uncovers a sexual transaction which foregrounds the concern over fidelity in commercial as well as marital relations, against the background of unstable religious and national identities.

\section{References}

Ackermann, Z. \& Schülting, S. (Eds.). (2011). Shylock nach dem Holocaust: zur Geschichte einer deutschen Erinnerungsfigur. Berlin: De Gruyter.

\footnotetext{
${ }^{5}$ Lisa Jardine has shown, for example, the shrewd and intricate negotiation of contracts and financial loans in the Hapsburg Empire in the early sixteenth century which ensured profitable commercial and political gains from colonization in the new world, natural resources, and marriage with a king's daughter (1996, pp. 277-87). The conflicts of national and personal interests or the dictates of the Church on usury that arose from this commodity culture were often hotly debated against the background of the Reformation, power struggles between European nations, and the military threat of an expansionist Ottoman Empire (Jardine, 1996, p. 326-76). Gil Anidjar has theorized the trope of blood in the play as engaging with this economic discourse in the flow of money in the Christian imagination, which sets up the Jew as an economic enemy (2014, p. 150-53).
} 
Achinstein, S. (2001). John Foxe and the Jews. Renaissance Quarterly, 54(1), 86120.

Adelman, J. (2008). Blood relations: Christian and Jew in The Merchant of Venice. Chicago: Chicago University Press.

Alexander, C. M. S., \& Wells, S. (Eds.). (2000). Shakespeare and race. Cambridge: Cambridge University Press.

Anidjar, G. (2014). Blood: A critique of Christianity. New York: Columbia University Press.

Bartels, E. (2008). Speaking of the Moor: From Alcazar to Othello. Philadelphia: University of Pennsylvania Press.

Berek, P. (1998). The Jew as Renaissance Man. Renaissance Quarterly, 51(1), 12862.

Berger, H. (2010). Mercifixion in The Merchant of Venice: The riches of embarrassment," Renaissance Drama 38, 3-45.

Berley, M. (1999). Jessica's Belmont Blues: Music and merriment in The Merchant of Venice. In P. C. Herman (Ed.), Opening the borders: Inclusivity in early modern studies (pp. 185-205). Newark, DE: University of Delaware Press.

Bovilsky, L. (2008). Barbarous Play: Race on the English Renaissance Stage. Minneapolis: University of Minnesota Press.

Bulwer, J. (1654). A View of the People of the Whole World. London: William Hunt, Blank, P. (2003). Shakespeare and the mismeasure of Renaissance man. Ithaca: Cornell University Press.

Bodian, M. (1999). Hebrews of the Portuguese nation: Conversos and community in early modern Amsterdam. Bloomington: Indiana University Press.

Bromley, J. M. (2012). Intimacy and sexuality in the age of Shakespeare. Cambridge: Cambridge University Press.

Brown, B. D. (1929). Mediaeval prototypes of Lorenzo and Jessica. Modern Language Notes,44(4), 227-32.

Bullough, V. L. and Bullough, B. (1993). Cross dressing, sex, and gender. Philadelphia: University of Pennsylvania Press.

Campos, E. (2002). Jews, Spaniards, and Portingales: Ambiguous identities of Portuguese Marranos in Elizabethan England. ELH 69 (3), 599-616.

Cattley, S. R. Ed. (1837). The Acts and Monuments of John Foxe. 20088 Vols. London: Seeley \& Burnside.

Charney, M. (1979). Jessica's turquoise ring and Abigail's poisoned porridge: Shakespeare and Marlowe as rivals and imitators. Renaissance Drama 10, 3344.

Cohen, W. (1985). Drama of a nation: Public theatre in Renaissance England and Spain. Ithaca: Cornell University Press.

Cox, C. (2000). Neither Gentile nor Jew: Performative subjectivity in The Merchant of Venice. Exemplaria 12, 359-83. 
Cressy, D. (1996). Gender trouble and cross-dressing in early modern England. Journal of British Studies, 35(4), 438-465.

Delgado de Torres, 0. (1994). Reflections on patriarchy and the rebellion of daughters in Shakespeare's Merchant of Venice and Othello. Interpretation 21(3), 333-353.

Dobbins, A. C. \& Battenhouse, R.W. (1976). Jessica's morals: A theological view. Shakespeare Studies 9, 107-20.

Eliav-Feldon, M. (2012). Renaissance imposters and proofs of identity. Houndsmill and New York: Palgrave Macmillan.

Ephraim, M. (2008). Her 'flesh and blood': Jessica's mother in The Merchant of Venice. In her Reading the Jewish Woman on the Elizabethan Stage (pp. 137-52). Leicester: Ashgate.

Fisch, H. (1971). The dual image: The figure of the Jew in English and American literature. London: World Jewish Library.

Foxe, J. (1578). A sermon preached at the Christening of a certaine Jew, at London by John Foxe conteining an exposition of the xi chapter of S. Paul to the Romanes. (J. Bell, trans.). London: Christopher Barker. Fascimile: http://quod.lib.umich.edu/e/eebo/A01136.0001.001?rgn=main;view=fulltex $\mathrm{t}$

Green, D. (2003). The double life of Doctor Lopez: Spies, Shakespeare and the plot to poison Elizabeth I. London: Century.

Groebner, V. (2009). The carnal knowing of a coloured body: Sleeping with Arabs and blacks in the European imagination, 1300-1550. In Eliav-Feldon, M., Isaac, B. \& Ziegler J. (Eds.). The origins of racism in the West, (pp. 217-231). Cambridge: Cambridge University Press.

Gross, J. J. (1994). Shylock: Four hundred years in the life of a legend. London: Vintage.

Hall, K. (2006). Guess who's coming to dinner? Colonization and miscegenation in The Merchant of Venice. Reprinted in L.S. Marcus (Ed.), Shakespeare, William. The Merchant of Venice (pp. 288-304). New York: W.W. Norton.

Hamilton, S. (2003). Shakespeare's daughters. Jefferson, NC: Macfarland.

Harris, A.J. \& Rubinstein F. (2004). Jessica's bawdy 'interlude' in The Merchant of Venice.English Language Notes 42 (2), 11-28.

Harris, J. G. (1998). Foreign bodies and the body politic: Discourses of social pathology in early modern England. Cambridge: Cambridge University Press.

Harris, J. G. (2004). Sick economies: Drama, mercantilism, and disease in Shakespeare's England. Philadelphia: University of Pennsylvania Press.

Heine, H. (1906). The works of Heinrich Heine. (G. Leland Trans.) London: Heinemann.

Hinley, J.L. (1980). Bond Priorities in The Merchant of Venice. Studies in English Literature 20, 217-239. 
Howard, Jean E. (1988). Cross dressing, the theatre, and gender struggle in Early Modern England. Shakespeare Quarterly, 39, 418-440.

Japtok, M. \& Schleiner W. (1999). Genetics and 'race' in The Merchant of Venice. Literature and Medicine 18 (2), 155-172.

Jardine, L. (1983). Still harping on daughters: Women and drama in the age of Shakespeare. Brighton: Harvester Press.

Jardine, L. (1996). Worldly goods: A new history of the Renaissance. New York: W.W. Norton.

Jordan, W. D. (2000).First impressions. In L.Back \& J. Solomos (Eds.), Theories of race and racism: A reader (pp. 33-50). London: Routledge.

Kaplan, M. Lindsay. (2007). Jessica's mother: Medieval constructions of Jewish race and gender in The Merchant of Venice. Shakespeare Quarterly 58, 1-30.

Katz, D. S. (1999). Shylock's gender: Jewish male menstruation in early modern England. Review of English Studies 50, 440-462.

Kruger, S. F. (2006). The spectral Jew: Conversion and embodiment in medieval Europe. Minneapolis: University of Minnesota Press.

Lampert, L. (2004). Gender and Jewish difference from Paul to Shakespeare. Philadelphia: University of Pennsylvania Press.

Landau, Aaron. (2006). Jews and Moors at the crossroads: Female conversion in The Merchant of Venice and Don Quixote. In C. Goodblatt and H. Kressel (Eds.), Tradition, heterodoxy, and religious culture(pp. 391-403). Beer-Sheva: BenGurion University of the Negev.

Levin, C. and Watkins, J. (2009). Shakespeare's foreign worlds: National and transnational identities in the Elizabethan age. Ithaca: Cornell University Press. Loomba, A. (2002). Shakespeare, race, and colonialism. Oxford: Oxford University Press.

Lupton, J. R. (2005).Citizen-saints: Shakespeare and political theology. Chicago: University of Chicago Press.

Maccoby, H. (2006). Antisemitism and modernity: Innovation and continuity. London: Routledge.

Mentz, S. R. (2003). The fiend gives friendly counsel: Launcelot Gobbo and polyglot economics in The Merchant of Venice. In L. Woodridge (Ed). Money in the age of Shakespeare (pp. 177-87). Houndmills and New York: Palgrave Macmillan.

Metzger, M. J. (1998). 'Now by my hood, a Gentle and no Jew': Jessica, The merchant of Venice, and the discourse of early modern English identity. Publications of the Modern Language Association of America 113(1), 52-63.

Middleton, I. (2015). A Jew's daughter and a Christian's wife: Performing Jessica's multiplicity in The Merchant of Venice. Shakespeare Bulletin 33 (2), 293-317. Modder, M. F. (1960). The Jew in the literature of England. New York: Meridian Books. (Originally published 1939). 
Mounsey, C. (Ed.) (2001). Changing sex in early-modern culture. Lewisberg PA: Bucknell University Press.

Nachshon E. \& Shapiro, M. (Eds.) (at press). Countering Shylock as Jewish stereotype. Cambridge: Cambridge University Press.

Newman, K. (2009). Essaying Shakespeare. Minneapolis: University of Minnesota Press.

Nirenberg, D. (2013). Anti-Judaism: The Western tradition. New York, Norton.

Oz, A. (1995). The yoke of love: Prophetic riddles in The Merchant of Venice. Newark: University of Delaware Press.

Questier, Michael.(1996). Conversion, politics and religion in England, 1580-1625. Cambridge: Cambridge University Press.

Ragussis, M. (1995). Figures of conversion: "The Jewish question" and English national identity. Durham, NC: Duke University Press.

Ragussis, N. (2007). The Jewess in nineteenth-century British literary culture. Cambridge: Cambridge University Press.

Reznick, I. (2012). Marks of distinction: Christian perception of Jews in the high middle ages. Washington DC: Catholic University of America Press.

Rosenshield, G. (2002). Deconstructing the Christian merchant: Antonio and The Merchant of Venice. Shofar: An Interdisciplinary Journal of Jewish Studies, 20 (2), 28-51.

Scrivener, M. (2011). Jewish representation in British literature, 1780-1840: After Shylock. Houndmills and New York: Palgrave Macmillan.

Shakespeare, W. (2006). The Merchant of Venice: Authoritative text, sources and contexts, criticism, rewritings and appropriations. Ed. Leah S. Marcus. New York: W.W. Norton.

Shapiro, J. (1996). Shakespeare and the Jews. New York: Columbia University Press. Shell, M. (1982). Money, language, and thought: Literary and philosophical economies from the medieval to the modern era. Berkeley: University of California Press.

Shoulson, J. S. (2013). Fictions of conversion: Jews, Christians, and cultures of change in early modern England. Philadelphia: University of Philadelphia Press.

Slights, C. (1980). In defense of Jessica: The runaway daughter in The Merchant of Venice. Shakespeare Quarterly, 31(3), 357-68.

Sinsheimer, H. (1947). Shylock, the history of a character, or the myth of the Jew. London: Gollancz.

Stelling, L. (2006). Cultures of conversion in The Merchant of Venice. Unpublished MA Thesis. University of Utrecht, August 2006. http://igiturarchive.library.uu.nl/student-theses/2007-

0124200112/Cultures\%20of\%20Conversion\%20in\%20The\%20Merchant\%2 0of\%20Venice.doc Internet. 
Tassi, M. A. (2011). Women and revenge in Shakespeare. Selinsgrove: Susquehama University Press.

Vitkus, D. J. (2008). Turning Turk: English theatre and the multicultural Mediterranean, 1570-1630. Houndmills and New York.

Young, R. J. C. (1995). Colonial desire: Hybridity in theory, culture and race. London: Routledge.

Ziegler, J. (2009). Physiognomy, science, and proto-racism, 1200-1500. In EliavFeldon, M., Isaac, B. \& Ziegler J. (Eds.) The origins of racism in the west. Cambridge: Cambridge University Press.

\section{Contact}

Professor Efraim Sicher

Abrahams-Curiel Department of Foreign Literatures \& Linguistics

Ben-Gurion University of the Negev

Beer-Sheva 84105

Israel

e-mail: sicher@bgumail.bgu.ac.il 